\title{
BIOLOGY
}

\section{TO STUDY THE DYNAMICS OF THE FORMATION OF EXTRACELLULAR AND INTRACELLULAR CARBOHYDRATES ON MEDIA WITH LIGNIN- CONTAINING WASTE SYNTHESIZED BY SOME BASIDIAL FUNGI}

\author{
candidate of biological sciences Abylaeva Baktygul Akmatalievna, \\ candidate of biological sciences Moldaliev Zhoomart Tumakovich,
}

Osh State University, Osh, Kyrgyzstan

DOI: https://doi.org/ 10.31435/rsglobal_ws/28022019/6351

\section{ARTICLE INFO}

Received: 14 December 2018

Accepted: 21 February 2019

Published: 28 February 2019

\section{KEYWORDS}

Intercellular (LNC), extracellular (NKL), deep cultivation of basidial fungi.

\begin{abstract}
The dynamics of the formation of intra- and Intercellular carbohydrates during deep cultivation of some species of basidomycetes on media with lignin-containing waste. The experiments have shown that plant waste from agriculture containing different amounts of lignocellulose is actively utilized by the above-mentioned fungi, capable of synthesizing a sufficient amount of both extracellular and intracellular carbohydrates.
\end{abstract}

Citation: Abylaeva Baktygul Akmatalievna, Moldaliev Zhoomart Tumakovich. (2019) To Study the Dynamics of the Formation of Extracellular and Intracellular Carbohydrates on Media with Lignin-Containing Waste Synthesized by Some Basidial Fungi. World Science. 2(42), Vol.1. doi: 10.31435/rsglobal_ws/28022019/6351

Copyright: (C) 2019 Abylaeva Baktygul Akmatalievna, Moldaliev Zhoomart Tumakovich. This is an open-access article distributed under the terms of the Creative Commons Attribution License (CC BY). The use, distribution or reproduction in other forums is permitted, provided the original author(s) or licensor are credited and that the original publication in this journal is cited, in accordance with accepted academic practice. No use, distribution or reproduction is permitted which does not comply with these terms.

In the process of cultivation and preparing for the sale of products and agricultural activities a large amount of agricultural waste is generated.

Lignin-containing agricultural waste can be used for a variety of purposes, in particular to generate energy while increasing biomass and reducing environmental pollution. With the help of microorganisms they can be converted into proteins, carbohydrates and other biologically active substances [1].

As a result of fermentation, the substrate is enriched not only with protein, but also easily digestible carbohydrates, the increase of which is due to the degradation of hemicelluloses, cellulose, pectin and other polysaccharides [4].

Therefore, in recent years, special attention is paid to the microbial biosynthesis of polysaccharides and widely studied the conditions of biodegradation of lignocellulosic waste for use in various fields of biotechnology.

In the southern region of Kyrgyzstan, a large number of rice, cotton and corn are grown. Rice straw, rice husks and corn cobs have found little rational use untie the present time. Their nutritional value, determined by the degree of availability of the polysaccharide complex to the enzyme systems of the body, is low due to the fact that about $45-50 \%$ of polysaccharides are difficult to hydrolyze. Therefore, to increase the digestibility of lignin-containing waste by increasing it easily accessible carbohydrates allows substrate treatment as physico-chemical and biological methods. 
The aim of this work is to study the dynamics of the formation of extracellular and intracellular carbohydrates in deep cultivation of some types of basidial fungi on media with lignincontaining waste.

\section{Experimental part:}

As an object, we used local strains of basidiomycetes Pleurotus ostreatus (xylosupprofit) and Fomes fomentarius (xyloparasite), related to the orders of Agaricales Aphillophorales, isolated from the poplar trunk of the park cultures of Osh city. In the process of screening, we selected mushrooms as an active strain of cellulose-depleting ability.

Fungi were cultured in a deep way on nutrient media containing the following plant waste: rice straw, rice husk and corn cobs. Cultivation was carried out in a deep way at a temperature of 280$300 \mathrm{C}$ in conical flasks of Erlenmeyer with a volume of $500 \mathrm{ml}$ with $200 \mathrm{ml}$ of the nutrient medium, pH 6.5 for 3 to 30 days on circular rockers with a rotation speed of $250 \mathrm{rpm}$.to determine the synthesis of extracellular carbohydrates, samples were taken every three days. Total carbohydrate content was determined by Dubois method [3].

The amount of grown biomass was determined by weight method, $\mathrm{pH}$ was determined $\mathrm{pH}$ meter.

At the end of growing the mycelium of the fungus was separated from the culture liquid by filtering on the Buchner funnel under vacuum. The mycelium was thoroughly washed with distilled water. The biomass was ground with quartz sand until the complete destruction of the mycelium hyphae. The homogenate was centrifuged for $15 \mathrm{~min}$ at $8000 \mathrm{Rev} \backslash \mathrm{min}$ Separated the supernatant from the homogenate. Further, they determined the content of carbohydrates, difficult and easily hydrolyzed hemicellulose polysaccharides.

\section{Results and discussion.}

A characteristic feature of these fungi is the ability to synthesize cellulolytic and lignolytic enzymes, which allows to utilize the components of lignocellulosic vegetable waste.

As a result of the studies, it was shown that both in the culture fluid and in the cell-free homogenate of fungi, the total carbohydrate content is from 26.5 to $41.4 \mathrm{mg} / \mathrm{ml}$.according to paper (BX) and thin - layer chromatography (TLC), carbohydrates consist of mono -, oligo-and polysaccharides, as well as uronic acids and includes mainly glucose, xylose, galactose, arabinose, mannose, rhamnose and galacturonic acid. According to the ability to biosynthesis of carbohydrates, the fungi can be arranged in the order of decreasing their ability to biosynthesis) P. Ostreatus > fomentarius [2].

Table 1 presents a study of the dynamics of carbohydrate formation: it is shown that the culture of the fungus R. ostreatus (A), grown on a medium containing rice straw, is able to accumulate in the culture liquid significant amounts of total carbohydrates on the 12th day to $(21.5 \mathrm{mg} / \mathrm{ml})$, and in the intracellular homogenate there are gradual increases to $(24.0 \mathrm{mg} / \mathrm{ml})$. Other quantitative indices of carbohydrate accumulation were obtained during the cultivation of the fungus Fomes fomentarius (B).

In this case, there is a gradual increase in the concentration of up to $(17.5 \mathrm{mg} / \mathrm{ml})$ carbohydrates in the culture liquid with a maximum accumulation on the 15th day of growth. The greatest accumulation of carbohydrates in the intracellular homogenate of the above-mentioned fungus was found on the 12th $(20.0 \mathrm{mg} / \mathrm{ml})$ day of producer growth. When studying the accumulation of carbohydrates by the studied fungi on the medium with corn ears, it was observed that there is a parallel accumulation of carbohydrates in both the culture fluid and the mycelium of fungi.

However, this causes an offset time of maximum accumulation of carbohydrates. For example: the maximum accumulation of carbohydrates by the fungus Pleurotus ostreatus occurs on the 12th $(27.0 \mathrm{mg} / \mathrm{ml})$, and in the intracellular homogenate on the 15 th day of cultivation $(24.7 \mathrm{mg} / \mathrm{ml})$. The formation of carbohydrates in the 12-th and 15-th days of cultivation of the intracellular carbohydrate occurs on this medium, and a constant concentration of carbohydrates with a maximum on the 6-th day of growth $(23.5 \mathrm{mg} / \mathrm{ml})$ is observed on the 12-th and 15-th day of cultivation $(18.0 \mathrm{mg} / \mathrm{ml})$. Similarly, the dynamics of the formation of carbohydrates and fungi Pleurotus ostreatus has been studied. Fomentarius, where the maximum accumulation of carbohydrates in a culture medium containing rice husk occurs on the 18th and 15 th day $(20.5 \mathrm{mg} / \mathrm{ml})$ of cultivation.

When growing mushrooms on these substrates, their utilization occurs with the formation of biologically valuable and active substances. In the process of growing mushrooms from 10 days to 30 days, a decrease of the content of polysaccharides [5, p. 66]. 
Table 1. Total carbohydrate content in culture liquid and mycelium homogenate depending on the time of cultivation on lignin-containing waste media.

\begin{tabular}{|l|l|l|l|l|l|l|l|l|l|l|l|l|l|l|l|}
\hline Fungus & Substrates & \multicolumn{9}{|c|}{ Cultural liquid, mg/ml } & \multicolumn{1}{|c|}{ Mycelium, mg/g } \\
\cline { 3 - 12 } & & 3 & 6 & 9 & 12 & 15 & 18 & 21 & 3 & 6 & 9 & 12 & 15 & 18 & 21 \\
\hline $\begin{array}{l}\text { P. Ostre } \\
\text { atus } \\
\begin{array}{l}\text { F. fomen } \\
\text { tarius }\end{array}\end{array}$ & I & 9,0 & 11,6 & 13,1 & 21,5 & 20,3 & 18,3 & 15,0 & 10,1 & 14,2 & 17,0 & 19,5 & 24,5 & 26,0 & 21,0 \\
\hline $\begin{array}{l}\text { P. Ostre } \\
\text { atus } \\
\begin{array}{l}\text { F. fomen } \\
\text { tarius }\end{array}\end{array}$ & II & 10,0 & 8,5 & 12,0 & 18,2 & 17,5 & 14,0 & 12,3 & 12,8 & 19,7 & 20,0 & 13,0 & 12,3 & 11,9 & 9,8 \\
\hline $\begin{array}{l}\text { P. Ostre } \\
\text { atus } \\
\begin{array}{l}\text { F. fomen } \\
\text { tarius }\end{array}\end{array}$ & III & 9,2 & 12,6 & 15,1 & 21,5 & 24,7 & 19,2 & 15,0 & 12,1 & 16,2 & 17,0 & 27,0 & 21,5 & 26,0 & 20,0 \\
\hline
\end{tabular}

Note: I-rice straw, II-corn cob, III - rice husk.

For the subsequent full assessment of the degree of utilization of lignocellulosic waste by fungi Pleurotus ostreatus and Fomes fomentarius studied the chemical composition of plant substrates used in this work. Table 2 shows the chemical composition of plant waste before the cultivation of fungi.

Table 2. Polysaccharide content (\% of dry matter) in plant agricultural waste prior to mushroom cultivation

\begin{tabular}{|l|l|l|l|l|}
\hline \multirow{2}{*}{ Plant species } & \multicolumn{4}{|c|}{ Polysaccharides g/ ml } \\
\cline { 2 - 5 } & $\begin{array}{c}\text { Water-soluble } \\
\text { polysaccharides }\end{array}$ & $\begin{array}{c}\text { Pectin } \\
\text { substances }\end{array}$ & $\begin{array}{c}\text { Hemicellulose } \\
-A\end{array}$ & Hemicellulose -B \\
\hline Rice straw & 2.72 & 1.92 & 3.0 & 2.9 \\
\hline Corncob & 11.2 & 1.84 & 2.12 & 3.7 \\
\hline
\end{tabular}

The facts of the table shows that the content of polysaccharides is different and the highest content of water-soluble polysaccharides and hemicellulose- $\mathrm{B}$ is observed on the corn cob and is $11.2 \%$ and hemicellulose -B 3.7\%. Rice straw contains fewer polysaccharides of water-soluble polysaccharides, pectin substances and hemicellulose -B 2.72\%, $1.92 \%$ and $2.9 \%$ respectively, and hemicellulose -A contains more than corn cob.

Of particular interest for subsequent studies was the study of the ability of these fungi to decompose native lignocellulosic plant waste.

Further, to study the component composition of extracellular and intracellular carbohydrates, polysaccharide fractions were isolated: water - soluble polysaccharide, pectin substances and hemicellulose.

To determine the component composition, each of the obtained polysaccharide fractions was subjected to complete acid hydrolysis and analyzed by paper and thin-layer chromatography. Determination of the qualitative composition of the polysaccharide from the culture liquid showed that it consists of the following basic Monomeric units: glucose, xylose, galactose, arabinose, mannose, rhamnose and galacturonic acid.

Table 3 shows the content of carbohydrates after the cultivation of fungi on plant waste.

Table 3. The content of carbohydrates produced by basidial fungi, on environments with different plant waste

\begin{tabular}{|l|l|l|l|l|l|l|}
\hline \multirow{2}{*}{ Fungus } & \multirow{2}{*}{ Substrates } & \multicolumn{5}{|c|}{ The yield of polysaccharides, \% } \\
\cline { 3 - 7 } & & Extracellular & \multicolumn{4}{|c|}{ Intracellular } \\
\cline { 3 - 7 } & & $\begin{array}{c}\text { Water-soluble } \\
\text { polysaccharides-1 }\end{array}$ & $\begin{array}{c}\text { Water-soluble } \\
\text { polysaccharides-2 }\end{array}$ & $\begin{array}{c}\text { Pectin } \\
\text { substances }\end{array}$ & $\begin{array}{c}\text { Hemicellulose } \\
\text {-A }\end{array}$ & $\begin{array}{c}\text { Hemicellulose } \\
\text {-5 }\end{array}$ \\
\hline $\begin{array}{l}\text { Fomes } \\
\text { fomentarius }\end{array}$ & I & 1.2 & 0.57 & 0.77 & 4.16 & 1.59 \\
\cline { 2 - 7 } $\begin{array}{l}\text { Pleurotus } \\
\text { ostreatus }\end{array}$ & I & 1.67 & 0.8 & 0.78 & 1.68 & 1.67 \\
\cline { 2 - 7 } & II & 1.39 & 1.11 & 1.6 & 3.45 & 1.67 \\
\hline
\end{tabular}

Note: I - rice straw, II - corn on the cob, Extracellular-from the culture fluid, Intracellular - from a homogenate of mycelium. 
The table shows that compared with the fungus Fomes fomentarius mushroom mushroom Pleurotus ostreatus synthesizes more polysaccharides. Therefore, to obtain on an industrial scale it is desirable to use fungi of the genus Pleurotus ostreatus According to [6, p. 935] when growing fungi on plant waste there is a splitting of polysaccharides to mono-, di - and oligosaccharides and the last, induce biosynthesis of the corresponding enzymes.

From the facts of table 2 it can be seen that in the culture liquid obtained in the medium with rice straw, the content of water-soluble polysaccharides is $1.2 \%-1.39 \%$. Water-soluble polysaccharides are powders of cream-yellow color, highly soluble in water. The main product of hydrolysis of polysaccharides grown on medium with corn cob obtained from the culture liquid of fungi Pleurotus ostreatus and Fomes fomentarius is glucose. The hydrolysates in the supernatant fluid received from all types of mushrooms, is also dominated by glucose.

On the medium with rice straw in the products of hydrolysis of the polysaccharide of the sedimentary fluid in fungi fomentarius, glucose was also found mainly. With the fungus P. ostreatus prevails xylose and glucose. Pectin substance prevails on the content of medium with corn cob -2.6\%. Galactose, glucose, arabinose, mannose, xylose and galacturonic acid were found in the products of hydrolysis of pectin substances by paper chromatography.

Hemicellulose is a dark brown powder, highly soluble in alkali. Aqueous solutions of the hemicelluloses do not give the iodine reaction for starch. The content of hemicellulose on medium with rice straw is high $4.16 \%$. Among the monosaccharides of the hemicellulose - and on the environment with corn cob and the environment rice straw, the predominant components are glucose and xylose.

Thus, the experiments have been showed that plant agricultural waste containing different amounts of lignocellulose is actively utilized by the above-mentioned fungi, capable of synthesizing a sufficient amount of both extracellular and intracellular carbohydrates. Among the nutrient media used, corn ears are a favorable environment for growth, development and synthesis in a sufficient amount of carbohydrates.

\section{REFERENCES}

1. A. Sasson \ Biotechnology: completion and hope. M.: "World" 1987. - S. 255.

2. Ahmedova Z.R., Beletskaya O. P. / / Cellulose and ligninases of basidiomycetes// Applied biochemistry and Microbiology. M.: 1993. - 823-828.

3. Dubois M., et al \\Anal. Biocem, 1956. 72. P.248-254.

4. Stakheev I. V., Kostina A. M., Babitskaya V. G., Scherba V. V. Carbohydrate composition of preparations of fungal origin obtained during deep and surface cultivation of crops. Microbiology. 1986. Vol. 55. P. 66-71

5. Ahmedova Z.R. Biodegradation of vegetable wastes Gripen. Education of biologically valuable products // Biotechnology. 1992. No. 5. P. 66.

6. Ahmedova Z.R., Beletskaya O.P., Dalimova G.N. // Microbiology, 1994. T. 63. Vol. 5. P. 935. 